\author{
Agnieszka Pawlak \\ ZaKŁad NAUK o RodZinie \\ UNIWERSYTET MEDYCZNY W ŁODZI \\ E-MAIL: AGNIESZKA.PAWLAK@UMED.LODZ.PL
}

\title{
„POCZYTAJ MI MAMO PRZEZ SKYPE'A”. NEGOCJOWANIE ZAKRESU I MODYFIKOWANIE RÓL RODZINNYCH W RODZINACH Z DOŚWIADCZENIEM EMIGRACJI ZAROBKOWEJ' ${ }^{1}$
}

\section{Wstęp}

Emigracja zarobkowa jest jednym z tych zagadnień, które doczekało się wielu opracowań, zarówno jeśli chodzi o polską socjologię, czy szerzej nauki społeczne, jak i socjologię amerykańską czy europejską. Od czasów słynnej pracy F. Znanieckiego i W. Thomasa Chłop polski w Europie i Ameryce pojawiło się sporo analiz dotyczących różnych aspektów emigracji zarobkowej zarówno w ujęciu makrosocjologicznym jak i mikrosocjologicznym. Dość dobrze zbadanymi kwestiami w odniesieniu do emigracji są ekonomiczne i polityczne skutki emigracji dla kraju wysyłającego i kraju przyjmującego. Jednakże każda nowa fala emigracji obfituje w wiele specyficznych zjawisk, które są eksplorowane przez kolejne pokolenia badaczy społecznych.

W efekcie ostatniej, poakcesyjnej fali emigracji zarobkowej z Polski, której początek datuje się na 1 maja 2004 roku (moment otwarcia większości rynków pracy krajów tak zwanej piętnastki dla nowych obywateli Unii Europejskiej) pojawiły się takie zjawiska, jak: wahadłowa strategia emigrowania, transnarodowe rodzicielstwo, eurosieroctwo czy syndrom niani (to ostanie zjawisko było znane już wcześniej, ale w ostatnim czasie przybrało na sile). W niniejszym artykule będę się zajmować transnarodowym rodzicielstwem. Skoncentruję się na tym, w jakim kierunku i w jakim zakresie ulegają modyfikacji role ojca, matki, dziecka i innych członków rodziny w rodzinach z doświadczeniem emigra-

Niniejszy artykuł jest rezultatem badań prowadzonych od 2012 roku ze środków przeznaczonych przez Uniwersytet Medyczny w Łodzi na rozwój młodych naukowców. Numer prac własnych: 502-03/6-074-04/502-64-041. 
cji zarobkowej o charakterze wahadłowym. Jak wygląda proces negocjacji tych ról rodzinnych? Jak przebiegają interakcje w rodzinie migracyjnej? W jakim sensie można mówić o rodzinach migracyjnych jako nienormatywnym modelu rodziny? Będą mnie też interesować społeczne i zdrowotne skutki funkcjonowania $\mathrm{w}$ rodzinie emigracyjnej $\mathrm{w}$ odniesieniu do samego emigranta $\mathrm{i}$ innych członków jego rodziny. Podstawą powyższych analiz będzie bogata literatura przedmiotu, jak i gromadzony od 2010 roku własny materiał badawczy, na który składają się wywiady jakościowe z emigrantami i ich rodzinami. Omówienie wyników badań własnych zostanie poprzedzone charakterystyką postakcesyjnej fali emigracji zarobkowej oraz przeglądem literatury przedmiotu dotyczącej rodziny migracyjnej.

\section{Polacy jako społeczeństwo transnacjonalnych nomadów}

Polacy stali się społeczeństwem nomadów. Co ciekawe, łatwiej jest nam wyemigrować w poszukiwaniu pracy i/lub lepszego życia do innego, nawet odległego kraju niż do innego miasta. Od kilkunastu lat obserwuje się w Polsce wzmożony zagraniczny ruch migracyjny, który przybrał najbardziej na sile w 2006 i 2007 roku, a zatem w 2-3 lata po wstąpieniu Polski do Unii Europejskiej. Z danych GUS przeanalizowanych przez Elżbietę J. Siek wynika, że w latach 2004-2007 na stałe wyemigrowało z Polski łącznie ok. 123 tys. osób, z czego ok. 85\% osiedliło się w Europie [Siek 2011: 149]. Dane GUS-u nie są jednak pełne, ponieważ obejmują jedynie wyjazdy osób, które emigrując dokonały formalnego wymeldowania z miejsca dotychczasowego zamieszkania w Polsce. W powyższych statystykach nie uwzględnia się natomiast migracji wahadłowych i migracji sezonowych. Skalę migracji można także zmierzyć porównując odpływ ludności na 1000 mieszkańców w latach 2002-2006. O ile w tym przedziale czasu odpływ ten wyniósł 0,70, o tyle w samym 2006 roku kształtował się na poziomie - 1,23 . W tym okresie największy odpływ ludności odnotowano w województwach opolskim i śląskim, trochę mniej w pomorskim, dolnośląskim i warmińsko-mazurskim [Sytuacja demograficzna Polski 2007:171].

Po 2004 roku jednym z najpopularniejszych kierunków emigracji Polaków stała się Wielka Brytania. W 2005 roku odnotowano dziesięciokrotny wzrost wyjazdów do tego kraju w porównaniu z poprzednim rokiem. Drugim pod względem popularności krajem emigracji jest RFN (głównie chodzi tu jednak o migracje sezonowe), a trzecim - Irlandia [Szczygielska 2013: 90-92]. 
Badacze emigracji zadają sobie również pytanie, czy populacja emigrantów wyróżnia się pod względem jakiś specyficznych cech od populacji nieemigrantów. Z dotychczasowych badań, których zestawienia i porównania dokonała Izabela Grabowska-Lusińska, wynika, że migrującą i niemigrującą część społeczeństwa różnicują płeć i wiek. Migranci są młodsi od niemigrantów. W grupie wyjeżdżających dominują mężczyźni. Wśród emigrantów częściej można także spotkać osoby bezrobotne (w momencie badania nie były nigdzie zatrudnione). Migranci są też częściej niż osoby nieposzukujące pracy za granicą osobami uczącymi się lub z wykształceniem wyższym aniżeli ogólna populacja [Grabowska-Lusińska 2012: 59]. Obserwujemy zatem przemiany w populacji emigrantów z Polski, gdyż jeszcze w latach dziewięćdziesiątych XX wieku i na początku XXI wieku pisano, iż wyjeżdżający Polacy mają nieporównanie niższe wykształcenie niż emigranci z Polski w latach osiemdziesiątych XX wieku [Korczyńska 2003: 85]. Należy jednak dodać, że emigracja z lat osiemdziesiątych miała głównie polityczny charakter. Emigrowali przede wszystkim działacze opozycji, którzy wywodzili się w dużej mierze ze środowisk inteligenckich.

Populację osób emigrujących można także charakteryzować tworząc różnego rodzaju typologie migrantów. Odwołam się tu do jednej z najbardziej znanych typologii autorstwa Johna Eade’a i współautorów, która powstała na podstawie badań emigrantów poakcesyjnych do Wielkiej Brytanii. Na bazie dwóch wymiarów, czyli oczekiwanych szans i planów życiowych oraz strategii migranckich, wyróżniono następujące typy migrantów:

1. „Bociany” (storks) - są to najczęściej migranci cyrkulacyjni, pracujących w sektorach generujących niskie dochody (catering, budownictwo, usługi domowe, rolnictwo). Dominują wśród nich migranci sezonowi.

2. "Chomiki” (hamsters) - migranci, którzy wyjeżdżają po to, aby zakumulować kapitał finansowy w celu zainwestowania go w Polsce.

3. „Poszukiwacze” (searchers) - młodzi, indywidualistycznie nastawieni ludzie, niemający żadnych konkretnych planów, a raczej pozostawiający wszystkie opcje jako otwarte, niezamykający się na żadne potencjalne możliwości.

4. „Pozostający” (stayers) - migranci, którzy przebywają w kraju emigracji już dłuższy czas i zamierzają pozostać w nim na stałe [Eade i współ. 2006; za: Grabowska-Lusińska 2012: 50].

Typologia ta posłuży mi do charakterystyki respondentów, którzy wzięli udział w moim badaniu. Tego typu przyporządkowanie badanego do określonego typu migranta pozwoli z jednej strony na jego pełniejszą charaktery- 
stykę, a z drugiej strony - typ migracji określa także podejmowane przez migranta strategie rodzicielskie.

Migracje są powodowane czynnikami niezależnymi od jednostki lub rodziny (czynniki globalne), jak i czynnikami zależnymi od jednostki lub rodzinny (czynniki subiektywne). Do czynników globalnych należą: brak pracy lub praca nisko płatna, nieadekwatność rodzaju i poziomu wykształcenia do zmieniającej się struktury rynku pracy, kształtowany społecznie (głównie medialnie) nacisk na podnoszenie standardu życia do określonego poziomu, niemożność realizacji preferowanego sposobu życia $\mathrm{z}$ uwagi na przejawianą $\mathrm{w}$ środowisku pracy i/lub społeczności lokalnej dyskryminację. Do czynników zależnych od jednostki i rodziny można zaliczyć: konieczność spłaty zaciągniętych zobowiązań, chęć realizacji planów (otworzenie własnego biznesu, budowa domu, wyjazd na wakacje, wykształcenie dzieci), konieczność zarobienia pieniędzy na leczenie członka rodziny (bardzo często jest to dziecko), chęć podwyższenia kwalifikacji, nauczenia się języka, poznania innej kultury. Czynniki te można rozpatrywać także w wymiarze kosztów i korzyści z wyjazdu. Podstawowym „Zadaniem” każdego emigranta posiadającego rodzinę i mającego na względzie własne dobro, jak i dobro pozostałych członków rodziny jest zrobienie bilansu kosztów i korzyści.

Jednym z kosztów emigracji jest obciążenie pracą, co przy zazwyczaj nie najlepszych warunkach mieszkaniowych i strategii maksymalnego oszczędzania zarobionych pieniędzy, może mieć negatywny wpływ na zdrowie osób wyjeżdżających. Dotychczas nie podjęto wielu badań dotyczących zdrowotnych skutków emigracji wahadłowych. Jednym z pierwszych polskich badaczy, który zainteresował się tym problemem, był Ludwik Landau, który w pracy z 1966 roku dokonał analizy dwóch kwestii: utraty zdrowia wśród emigrantów na skutek przepracowania i niedostatecznego odżywiania się lub spożywania nieświeżych produktów oraz z powodu nieszczęśliwych wypadków [Landau 1996: 126; za: Korczyńska 2003: 73].

Nowym wątkiem podejmowanym przez badaczy emigracji jest transnacjonalizm, który wyraża się utrzymywaniem przez migranta bliskich kontaktów zarówno z krajem emigracji, jak i z krajem pochodzenia, a nawet związków z kolejnymi krajami emigracji. W ten sposób emigrant nabywa „tożsamość dwukulturową", która przejawia się między innymi w posiadaniu dwóch lub więcej „domów rodzinnych” w różnych krajach. Imigrant transnacjonalny nie odczuwa potrzeby aklimatyzacji do nowego środowiska w takim zakresie jak migrant tradycyjny. Wielu natomiast odczuwa zawieszenie między obydwoma krajami i brak poczucia przynależności i lojalności [Kubitsky 2012:21]. Tak więc transnacjonalizm odnosi się do sposobu funkcjonowania migranta w dwóch 
światach: „starym” - pochodzenia i „nowym” - przyjmującym [Szczygielska 2013: 19]. Poakcesyjni emigranci zarobkowi to w dużej mierze właśnie emigranci transnacjonalni żyjący w dwóch miejscach jednocześnie - w kraju pochodzenia, gdzie jest bliższa i dalsza rodzina, znajomi, sąsiedzi i inne grupy odniesienia oraz gdzie wydaje się lub inwestuje zarobione pieniądze, a także w kraju emigracji, gdzie jest praca. Nierzadkim zjawiskiem, chociaż dotychczas nie oszacowano jego skali, jest tworzenie nowej rodziny na emigracji, która pełni rolę alternatywy dla rodziny pozostawionej w kraju. W ten sposób posiadanie dwóch „domów rodzinnych” nabiera nie tylko metaforycznego, ale również realnego znaczenia.

Transnacjonalne funkcjonowanie umożliwiają nowoczesne narzędzia komunikacji. Jedną z podstawowych form kontaktu emigranta $\mathrm{z}$ rodziną jest telefon komórkowy oraz Internet. To pierwsze narzędzie komunikacji pełni funkcję „, apteczki pierwszej pomocy”. Z kolei Internet jest nie tylko narzędziem komunikacji, ale także „ośrodkiem informacyjnym”, gdyż los emigranta w nowym kraju w dużym stopniu zależy od uzyskania wielu informacji [Kubitsky 2012: 21].

Powyższa z konieczności niepełna charakterystyka obecnej fali emigracji zarobkowej pozwala na wysunięcie kilku wniosków. Emigranci stanowią znaczącą grupę społeczną. Wyjeżdżają powodowani różnymi motywami, najczęściej jest to motyw zarobkowy, rzadziej - chęć sprawdzenia się, przygody. Zatem, więcej jest wśród emigrantów „bocianów” czy „chomików” niż „poszukiwaczy”. Nowoczesne formy komunikacji wpłynęły na rozwój transnacjonalnego stylu życia polegającego na zarabianiu „tam” i życiu „tu”, co przekłada się na budowanie dualnych tożsamości. Utrzymująca się od lat na wysokim poziomie popularność zagranicznych wyjazdów zarobkowych nie pozostaje bez wpływu na jakość relacji rodzinnych. Wobec powszechności emigracji powstaje pytanie, czy rodzinę migracyjną należy ciągle jeszcze postrzegać w kategoriach nienormatywności lub, jak twierdzą niektórzy, patologii.

\section{Rodzina migracyjna w świetle literatury przedmiotu - patologia czy norma?}

Rodzina migracyjna była już przedmiotem kilku badań, do których będę się tu odwoływać. Czasami wątek rodzicielstwa na odległość i kontaktów migranta $\mathrm{z}$ rodziną stanowi główny przedmiot badań, czasem jest jednym z wielu wątków podejmowanych w ramach badania wybranej grupy emigrantów. Tak 
było w przypadku badań emigracji sezonowej do Niemiec przeprowadzonych w 1999 i 2000 roku przez Joannę Korczyńską. Wniosek z powyższych badań jest taki, że już trzymiesięczna nieobecność w domu może niekorzystnie wpływać na życie rodzinne i być przyczyną kłopotów z dziećmi [Korczyńska 2003: 157]. Ponadto, rodzinę migracyjną można badać przez pryzmat doświadczeń rodziców i/lub losów dzieci.

Reakcje dzieci na wyjazd rodziców zależą także od wieku dziecka. Można wyróżnić kilka typów tych reakcji:

1. Dzieci do lat 7 przeżywają kryzys emocjonalny związany z rozłąką z rodzicem, który może być zarówno krótkotrwały, jak i długotrwały.

2. Dzieci między 10 a 11 rokiem życia częściej doświadczają problemów $\mathrm{w}$ funkcjonowaniu społecznym oraz przejawiają problemy w nauce.

3. W grupie starszych dzieci zauważalna bywa radość z odzyskanej wolności i braku nadzoru ze strony dorosłych.

4. Dzięki migracji rodziców starsze dzieci mogą też stać się bardziej niezależne i odpowiedzialne [Michałek 2010: 162].

Dziecko w rodzinie rozłączonej w efekcie migracji jednego z rodziców przechodzi przez następujące etapy:

1. Etap podejmowania decyzji o wyjeździe.

2. Etap czekania na informacje od nieobecnego rodzica.

3. Etap adaptacji do nowej sytuacji.

4. Etap radzenia sobie $\mathrm{z}$ trudnościami, niepokojem.

5. Etap uczenia się radzenia sobie w życiu codziennym bez jednego lub obojga rodziców [Danilewicz, 2003: 103-142].

Badacz emigracji i emigrant Jacek Kubitsky w książce Psychologia emigracji analizuje różne wymiary tego zjawiska, w tym negatywne aspekty emigracji przejawiające się w zachowaniu dzieci. Zwraca między innymi uwagę na ustalenia psychologów klinicznych pracujący z rodzinami migrantów, którzy zauważyli analogię między objawami choroby sierocej a zachowaniem dzieci migrantów. Po dłużej nieobecności rodziców nie tylko nie okazują one radości, ale nawet nie chcą ich widzieć. Ciekawe, że część dzieci reaguje smutkiem i przygnębieniem dopiero po powrocie rodzica, mimo iż wcześniej mogło się wydawać, że dość dobrze znosi jego kilkutygodniową lub kilkumiesięczną nieobecność. Jeszcze inaczej reagują dzieci w wieku nastoletnim. Sytuacja emigracyjna zakłóca u nich naturalny proces wyzwalania się spod wpływu rodziców i poszukiwania własnej tożsamości. Taki nastolatek zamiast buntować się przeciw 
rodzicom często bierze na siebie rolę pocieszyciela, opiekuna, a nawet „rodzica rodziców" [Kubitsky 2012: 32].

Pedagodzy i psycholodzy wyodrębniają różne poziomy sieroctwa w zależności od nasilenia się zaburzeń w relacji z rodzicami:

1. Najwyższy - zupełny brak kontaktu z rodzicami.

2. Średni - sporadyczne, nieregularne kontakty dziecka $\mathrm{z}$ rodzicami.

3. Najniższy - kontakt dosyć częsty z różną częstotliwością, zainteresowanie rodziców sytuacją dziecka [za: Szczygielska 2013: 129].

Eurosieroctwo traktuje się jako rodzaj sieroctwa społecznego. Termin ten jest jednak bardzo różnie definiowany. W niektórych definicjach przyjmuje się zbyt szeroki zakres tego pojęcia włączając również sytuacje, kiedy dziecko zostało opuszczone przez jednego rodzica, który wyjechał do pracy za granicę [Kozak 2010: 113]. W innych definicjach bierze się pod uwagę kryterium braku kontaktu z emigrującym rodzicem. Podkreśla się także, iż zdarzają się sytuacje, w których separacja $\mathrm{z}$ rodzicem/rodzicami wpływa na poprawę sytuacji dziecka. Dzieje się tak, kiedy rodzice przed emigracją nie wypełniali w sposób prawidłowy funkcji opiekuńczej [Trusz, Kwiecień 2012: 40-43]. W kontekście omawiania zjawiska eurosieroctwa należy zwrócić uwagę na to, że w efekcie doniesień medialnych słowo „eurosierota” nabrało piętnującego znaczenia, co, jak pokazują wyniki badań polskich psychologów, może mieć wpływ na odbiór dzieci z rodzin migranckich przez otoczenie społeczne, w tym środowisko szkolne [Trusz, Kwiecień 2012].

Poza chorobą sierocą/eurosieroctwem oraz trudnościami związanymi z dorastaniem i budowaniem własnego, autonomicznego „ja” badając rodziny emigrantów brytyjscy psychiatrzy odkryli, że w tego typu rodzinach częściej obserwuje się objawy dysfunkcji i zaburzeń psychicznych u dzieci [Patino i in. 2005: za: Szczygielska 2013: 131].

Bardzo często problematykę rodzicielstwa na odległość i relacji między emigrującym rodzicem a dzieckiem/dziećmi porusza się badając emigrację kobiet. Podstawowym wnioskiem wysuwanym przez osoby zajmujące się migrantkami jest wpływ migracji zarobkowej na zwiększenie się egalitarności relacji w rodzinie na korzyść kobiet. Magdalena Muszel, analizując zachodnie dane dotyczące emigracji kobiet, zwłaszcza matek, zauważa, że pisze się o niej nie tylko w kategoriach trudnego doświadczenia, kojarzonego z poczuciem winy i bezradności w związku z pozostawieniem dzieci w kraju, ale także w kontekście zmiany tradycyjnego wizerunku kobiety i matki w rodzinie, której troska o dzieci może się także wyrażać przez przejęcie odpowiedzialności za materialny byt rodziny oraz zastępowania codziennej opieki relacjami na odległość [Muszel 2013; 
Szczygielska 2013: 126; Małek 2011: 39-47]. Tym niemniej podkreśla się, iż transnarodowe rodzicielstwo wiąże się z ogromnymi kosztami emocjonalnymi zarówno matek, jak i dzieci. Rhacel Salazar Parenas badająca filipińskie emigrantki nazywa tego rodzaju koszty „bólem macierzyństwa z daleka” i „bólem dorastania w transnarodowych rodzinach" [Parenas 2001: 370, 375].

Transnarodowe macierzyństwo odmiennie niż transnarodowe ojcostwo należy postrzegać przez pryzmat prac wykonywanych przez kobiety. Często są to prace w sektorze usług domowych, w tym praca niani. Zajmowanie się innymi dziećmi wpływa na sposób postrzegania siebie w roli matki oraz na sposób realizacji funkcji opiekuńczej na odległość. W przypadku mężczyzn nie mamy do czynienia z pracami, których specyfika może mieć bezpośredni związek $\mathrm{z}$ funkcją ojca. Ponadto, ciągle silny jest kulturowy stereotyp, iż główną funkcję rodzicielską spełniają matki. Tak więc ich wyjazd jest zazwyczaj naznaczony pewnym społecznym piętnem. W związku ze zjawiskiem pracy kobiet jako opiekunek pojawiło się pojęcie „drenażu opieki” [care-drain; Ehrenreich, Hochschild 2004], czyli utraty kapitału w postaci rodzicielskiej opieki, który jest transferowany za granicę. Bywa, że opiekowanie się dziećmi swoich pracodawców pełni funkcję zastępczego macierzyństwa i do pewnego stopnia może zaspokajać potrzebę opieki nad własnymi dziećmi. Konsekwencją zjawiska „drenażu opieki” jest tworzenie „globalnych łańcuchów opieki” [global care chains, Ehrenreich, Hochschild 2004], czyli sieci opieki nad pozostawionymi w kraju dziećmi, w której uczestniczą najczęściej kobiety z bliższej lub dalszej rodziny.

Izabela Szczygielska badając grupę starachowickich kobiet - emigrantek i analizując ich wypowiedzi dotyczące sytuacji w domu i możliwości realizacji roli rodzica oraz wypowiedzi ich dzieci pochodzące z wypracowań doszła do następujących wniosków:

- po wyjeździe matki konieczna była reorganizacja życia domowego, zmiany w harmonogramie codziennych obowiązków, które często w sposób trwały wpłynęły na funkcjonowanie tych rodzin.

- Nowe obowiązki zyskali nie tylko dorośli członkowie rodzin (ojciec, babcia, ciocia), ale i najstarsze dzieci.

- Wyjazd matki oznaczał ograniczenie nie tylko bezpośrednich kontaktów z nią, ale także z rodzicem pozostającym na miejscu z uwagi na jego przeciążenie dotychczasowymi i nowymi obowiązkami i brak dostatecznej ilości czasu dla dzieci.

- Pisząc o wyjeździe mamy dzieci często używały takich określeń, jak: opuszczenie, porzucenie, brak miłości. 
- Wiadomości przekazywane telefonicznie były niejako cenzurowane respondentki i członkowie ich rodzin nie byli do końca szczerzy podczas tych rozmów, chcąc chronić się wzajemnie przed niepotrzebnymi emocjami. Niektóre badane przyznawały, że wolały rzadziej kontaktować się z rodziną, gdyż częstszy kontakt rozbudzał ich tęsknotę [Szczygielska 2013: 184-203].

Należy zatem pamiętać, że rodzicielstwo na odległość ma swoje ograniczenia. Telefonicznie lub za pomocą łączy internetowych można przekazywać różnego rodzaju wskazówki, rady, napomnienia, ale dużo trudnej jest wyegzekwować określone zachowania. Ponadto, pewne konsekwencje czy ważne rozmowy są odraczane do czasu powrotu lub ponownego kontaktu, przez co mogą tracić na znaczeniu. Kolejne ciekawe zjawisko to „zawieszanie” negatywnych zachowań przez dzieci w trakcie bytności rodzica emigrującego w domu. Sytuacja taka neutralizuje narzekania opiekunów przebywających z dziećmi na co dzień. Nie mają oni „dowodów” na poparcie swoich słów o złym zachowaniu dzieci. Rodzic emigrujący bywa też traktowany jako „ostatnia instancja” w sprawach spornych między dziećmi lub między dziećmi a rodzicem stacjonarnym [Danilewicz 2003: 251]. Na podkreślenie zasługuje fakt, iż dzieci łatwiej znoszą migrację przeżycia niż migrację sukcesu. Łatwiej jest im zaakceptować wyjazd, który jest koniecznością, a nie wynikiem nadmiernie rozbudzonych potrzeb konsumpcyjnych [Gizicka, Gorbaniuk, Szyszka 2010: 25, 28].

Rodzina migracyjna jest badana nie tylko od wewnątrz, ale także niejako od zewnątrz. Analizuje się wówczas społeczny odbiór rodzin, w których jedno lub oboje rodziców wyjeżdżają do pracy za granicę. Nasilenie tego zjawiska jest tak duże, że można przyjąć, iż każdy zna przynajmniej jedną taką rodzinę. Z badań przeprowadzonych przez Dorotę Gizicką, Julię Gorbaniuk oraz Małgorzatę Szyszkę wynika, że respondenci najczęściej określali skalę występowania rodzin migracyjnych pomiędzy 20 a 40\%. Prawie co trzeci respondent uznał, że migracja ma negatywny wpływ na rodzinę (30,7\%), a jedynie $16 \%$ osób stwierdziło, że migracja ma pozytywny wpływ na rodzinę. Pozytywna ocena wpływu migracji zarobkowej na rodzinę była częstsza wśród osób, które w rodzinie pochodzenia doświadczyły emigracji jednego z rodziców. Do pozytywnych wpływów migracji zarobkowej respondenci zaliczyli głównie czynniki natury ekonomicznej, a wśród negatywnych aspektów na pierwszym miejscu wymienili tęsknotę dzieci za rodzicem/rodzicami. Ponadto, badani posiadający dzieci niemal dwa razy częściej niż osoby nieposiadające dzieci wyrażały opinię, że migracja ma negatywny wpływ na dzieci. Na negatywny wpływ migracji na dzieci częściej też wskazywały kobiety niż mężczyźni. Do pozytywnych aspek- 
tów migracji rodzica $\mathrm{z}$ punktu widzenia dziecka zaliczono wzrost samodzielności dzieci $(87,4 \%)$ oraz zacieśnienie więzi z rodzicem pozostającym w kraju $(81,1 \%)$. Z drugiej strony emigracja rodzica może powodować brak należytej kontroli i opieki ze strony drugiego rodzica $(81,1 \%)$ oraz rozluźnienie więzi $\mathrm{z}$ nieobecnym rodzicem (70,8\%). Ponad połowa badanych uznała także, iż wyjeżdżający rodzice mają świadomość ewentualnych negatywnych konsekwencji swojej decyzji o emigracji, którym w największym stopniu może zapobiec jak najczęstszy kontakt telefoniczny i mailowy. Co ciekawe, zdaniem większości respondentów za granicę powinien się udawać tylko ojciec lub oboje rodzice, ale na zmianę. W przypadku emigracji ojców nie wskazywano, w jakim wieku powinno być dziecko w momencie wyjazdu, a w przypadku emigracji matek większość respondentów uznała, że wyjechać mogą te kobiety, których dzieci mają więcej niż 10 lat [Gizicka, Gorbaniuk, Szyszka 2010: 77-130].

Warto zauważyć, że mamy tak naprawdę do czynienia z różnymi typami rodzin migracyjnych, których klasyfikacji i opisu dokonała Wioleta Danilewicz. Autorka na podstawie kryterium wspólnoty rodzinnej wyróżniła następujące typy rodzin migracyjnych:

1. Rodzina $\mathrm{w}$ rozpadzie strukturalnym - w rodzinie doszło do formalnego (rozwód) lub nieformalnego (porzucenie, zanik kontaktów, związek pozamałżeński) rozpadu. Rozpad strukturalny został poprzedzony rozpadem emocjonalnym.

2. Rodzina w rozpadzie emocjonalnym - w rodzinie ma miejsce poczucie rozpadu więzi małżeńskiej i rodzinnej. Dominuje negatywna ocena konsekwencji migracji. Ten typ różni od poprzedniego utrzymywanie kontaktu pomiędzy migrantami a rodziną.

3. Rodzina o zaburzonym charakterze wspólnoty - małżonkowie i dzieci mają poczucie rozluźnienia więzi emocjonalnych. Emigracja jest oceniana zarówno w kategoriach negatywnych jak i pozytywnych. Mimo trudności migranci starają się utrzymywać więzi emocjonalne z rodziną, a ich plany życiowe dotyczą rodziny.

4. Rodzina jako wspólnota rozłączona przestrzennie - $\mathrm{w}$ tej rodzinie ma miejsce wyraźnie poczucie wspólnoty rodzinnej oraz dominują pozytywne oceny wyjazdu zarobkowego.

5. Rodzina jako wspólnota emocjonalna - w tego typu rodzinach mamy do czynienia z wyraźnym poczuciem wspólnoty rodzinnej oraz z dominacją pozytywnych konsekwencji migracji [Danilewicz 2003: 199-210].

Powyższa typologia układa się w swego rodzaju kontinuum od rodziny jako wspólnoty emocjonalnej do rodziny rozłączonej strukturalnie. Czynnikami 
różnicującymi są stopień głębokości więzi między małżonkami oraz między małżonkami a dziećmi, a także ocena skutków migracji dla rodziny.

Wobec powszechności wyjazdów zarobkowych rodzina migracyjna staje się swego rodzaju normą społeczną, podobnie jak na przykład rodziny monoparentalne. I podobnie jak inne typy rodzin rodziny migracyjne mogą borykać się $\mathrm{z}$ różnego rodzaju problemami dotyczącymi między innymi wypełniania funkcji rodzicielskiej na odległość oraz wzajemnych relacji na linii rodzic stacjonarny - rodzic emigrujący, rodzic stacjonarny - dziecko/dzieci. Niektóre z możliwych problemów występują przez krótki okres, z innymi rodzina migracyjna musi sobie radzić przez dłuższy czas. Rodzaj podejmowanych strategii rodzicielskich zarówno przez wyjeżdżającego rodzica, jak i rodzica pozostającego $\mathrm{w}$ domu zależy od typu rodziny migracyjnej oraz wieku dzieci. Nie bez znaczenia jest też jakość relacji rodzinnych przed wyjazdem. Pozytywnym aspektem wyjazdu z punktu widzenia dzieci jest wzrost ich samodzielności, negatywnym - tęsknota za rodzicem oraz społeczne piętno eurosieroty, które może wpływać na sposób funkcjonowania dziecka w szkole i poza nią. Rodzajem antidotum na problemy, które mogą się w takiej rodzinie pojawić, jest częsty kontakt oraz sprawnie funkcjonująca sieć wsparcia.

\section{Rodzicielstwo na odległość - możliwości i ograniczenia. Rezultaty badań własnych}

Badanie, którego wyniki przedstawię, jest częścią projektu pod tytułem Poakcesyjna emigracja zarobkowa a model rodziny i ryzyko zdrowotne. Przedmiotem badań jest emigracja zarobkowa w kontekście różnego rodzaju ryzyk zdrowotnych, jakie się z nią wiążą. Związane $\mathrm{z}$ emigracją ryzyko jest również przedmiotem analizy w odniesieniu do rodziny emigranta. Definiuję ryzyko zdrowotne bardzo szeroko, włączając do tej definicji także zaburzenia relacji rodzinnych i szerszych - społecznych.

Teoretyczną bazą moich badań są następujące teorie:

1. Teorie odnoszące się ogólnie do zjawiska migracji: teoria społeczeństwa ryzyka U. Becka, teoria systemów-światów I. Wallersteina, teoria migranckiego kapitału społecznego, nowa ekonomiczna teoria migracji (New Economics of Labour Migration, NELM), teoria wypychania i przyciągania (push-pull theory), teoria stresu społecznego.

2. Teorie dotyczące rodziny migracyjnej: teoria transnarodowego macierzyństwa/rodzicielstwa, koncepcja globalnej sieci opieki. 
Punktem wyjścia badań były trzy hipotezy. Hipoteza pierwsza (H1) dotyczy relacji rodzic-dziecko: emigracja rodzica nie zaburza pełnienia ról rodzinnych, a jedynie modyfikuje sposób i zakres pełnienia tej roli. Kolejna hipoteza (H2), którą przyjęłam, brzmi: niezbędnymi czynnikami realizacji roli matki/ ojca na odległość są zarówno silne więzy między rodzicem a dzieckiem/dziećmi w okresie przed emigracją oraz odpowiedni wiek dzieci. Trzecia hipoteza (H3) dotyczy związku emigracji zarobkowej ze zdrowiem emigranta i jego rodziny i zakłada, że warunki pracy i życia na emigracji mają negatywny wpływ na możliwość funkcjonowania emigranta w innych kontekstach, w tym w kontekście rodzinnym.

Badanie zostało zrealizowane techniką wywiadu swobodnego w trzech grupach respondentów:

1. Wśród rodziców-emigrantów i ich pozostających w kraju partnerów (59 osób).

2. Wśród rodziców bez doświadczenia emigracji zarobkowej, którzy stanowili grupę kontrolną (15 osób).

3. Wśród emigrantów singli (40 osób).

Próba badawcza wynosi obecnie 114 osób. Wnioski z badań dwóch ostatnich grup zostaną tu pominięte. Charakterystykę badanych z pierwszej grupy przedstawiono $\mathrm{w}$ tabeli 1 . 


\begin{tabular}{|c|c|c|c|c|c|c|c|c|c|c|c|c|c|c|c|c|}
\hline 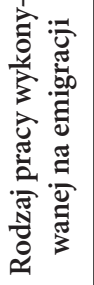 & 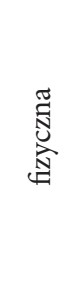 & 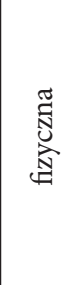 & 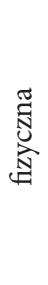 & 芯 & $\begin{array}{l}\stackrel{\pi}{\mathbb{N}} \\
\text { స్ట̆ }\end{array}$ & 芯 & 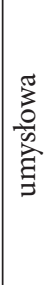 & 䔍 & 芯 & 芯 & 芯 & 芯 & 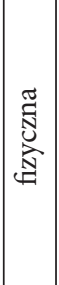 & 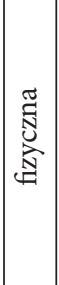 & 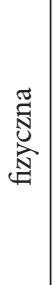 & 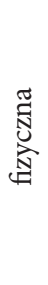 \\
\hline 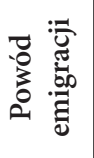 & 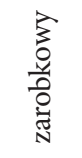 & 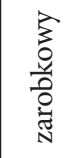 & 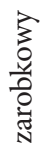 & 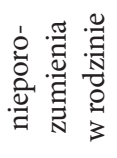 & 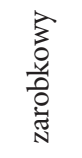 & 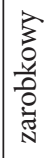 & 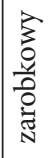 & 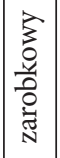 & 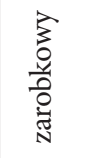 & 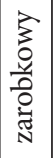 & $\begin{array}{l}3 \\
0 \\
0 \\
0 \\
0 \\
0 \\
3 \\
\text { N }\end{array}$ & 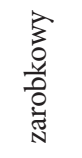 & 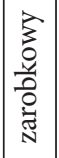 & 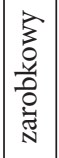 & 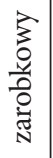 & 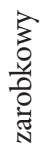 \\
\hline 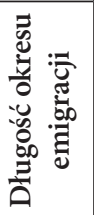 & $\frac{\pi}{\pi}$ & $\frac{\stackrel{\Xi}{\Xi}}{N}$ & 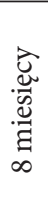 & $\frac{\frac{\pi}{\pi}}{\sigma}$ & 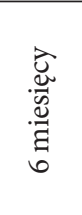 & $\begin{array}{l}\vec{z} \\
0 \text { on } \\
\text { in } \\
\text { v̂ }\end{array}$ & $\frac{\pi}{\frac{\pi}{m}}$ & 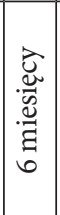 & 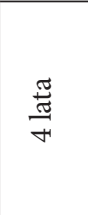 & 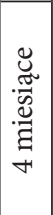 & 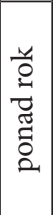 & 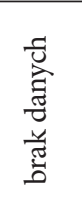 & 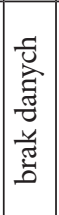 & $\frac{\pi}{\stackrel{\Xi}{N}}$ & 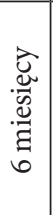 & $\frac{\pi}{6}$ \\
\hline 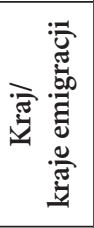 & 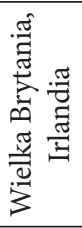 & 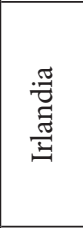 & 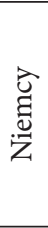 & $\begin{array}{l}\frac{\pi}{0} \\
\frac{\pi}{N} \\
\text { d. }\end{array}$ & 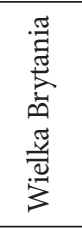 & 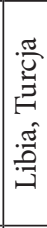 & 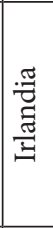 & 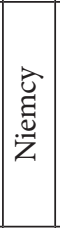 & 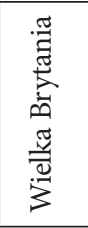 & 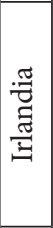 & 莺 & 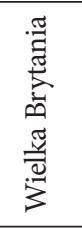 & 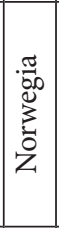 & 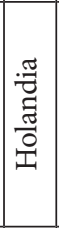 & 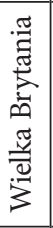 & 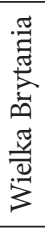 \\
\hline 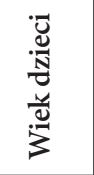 & $\stackrel{10}{i}$ & $\begin{array}{l}n \\
\hat{n} \\
\hat{0}\end{array}$ & $\ddot{n}$ & 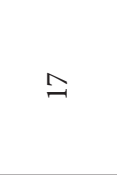 & 6 & 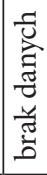 & $\because$ & 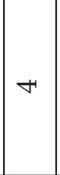 & 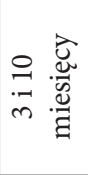 & ㄱ. & 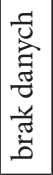 & 小 & $\begin{array}{l} \pm \\
= \\
= \\
0\end{array}$ & $\begin{array}{l}\vec{H} \\
\hat{\sigma}\end{array}$ & $\begin{array}{l}\hat{\omega n} \\
\hat{H} \\
\hat{n}\end{array}$ & $\stackrel{\overbrace{}}{\tilde{N}}$ \\
\hline 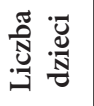 & - & $N$ & $\sim$ & - & - & $\sim$ & $\neg$ & - & $N$ & $\sim$ & $N$ & $\sim$ & $m$ & $v$ & $\sim$ & $\sim$ \\
\hline 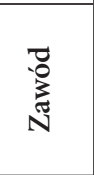 & 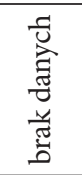 & 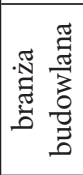 & 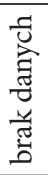 & 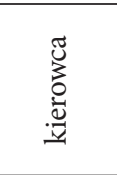 & 离 & 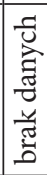 & 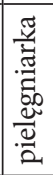 & 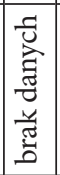 & 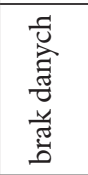 & 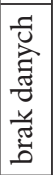 & 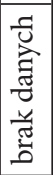 & 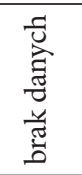 & 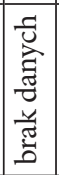 & 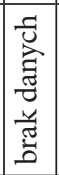 & 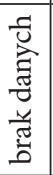 & 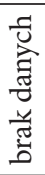 \\
\hline 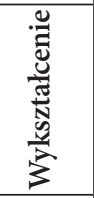 & \begin{tabular}{l} 
N \\
N \\
\multirow{3}{3}{}
\end{tabular} & 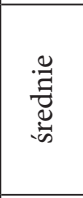 & 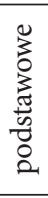 & 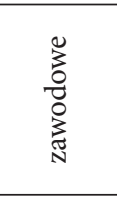 & 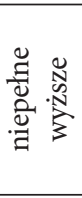 & 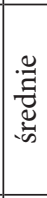 & 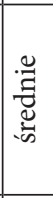 & 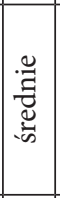 & 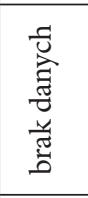 & 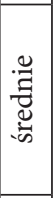 & 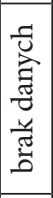 & 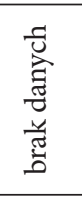 & 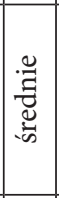 & 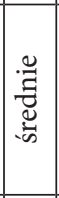 & 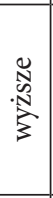 & 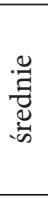 \\
\hline 光 & $\widehat{\curvearrowright}$ & ln & m & ले & ঐે & g) & ફे & $\stackrel{\infty}{\sim}$ & ' & 구 & I & , & అల & নे & $\stackrel{\infty}{\sim}$ & กิ \\
\hline 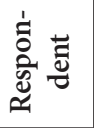 & $\begin{array}{c}\text { స్ } \\
\text { 至 }\end{array}$ & 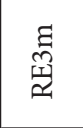 & $\underset{\Xi}{\Xi}$ & 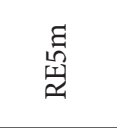 & 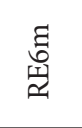 & $\underset{1}{1}$ & \begin{tabular}{l}
$\underline{y}$ \\
$\infty$ \\
का \\
\multicolumn{1}{c|}{}
\end{tabular} & 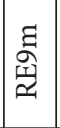 & 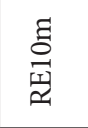 & $\begin{array}{l}\text { 큭 } \\
\text { 至 }\end{array}$ & 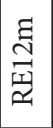 & 吉 & $\underset{\square}{\stackrel{\Xi}{二}}$ & 苂 & 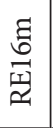 & $\stackrel{\Xi}{\Xi}$ \\
\hline$\stackrel{2}{2}$ & $\neg$ & $\sim$ & $m$ & 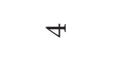 & $1 n$ & 6 & $n$ & $\infty$ & $a$ & 으 & $\exists$ & $\stackrel{\sim}{\sim}$ & 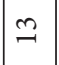 & $\Xi$ & $\stackrel{20}{-}$ & 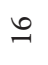 \\
\hline
\end{tabular}




\begin{tabular}{|c|c|c|c|c|c|c|c|c|c|c|c|c|c|c|c|}
\hline 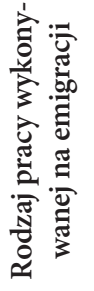 & 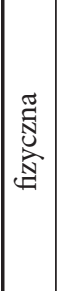 & 芯 & 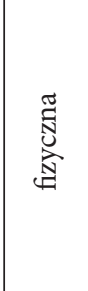 & 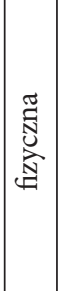 & 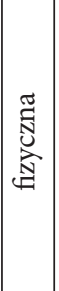 & 芯 & 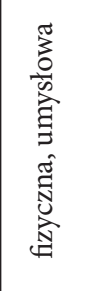 & 芯 & 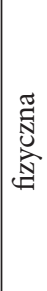 & 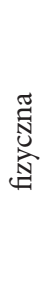 & 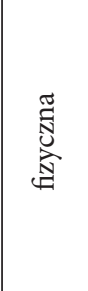 & $\begin{array}{l}\text { J్̃ } \\
\text { స్ㅂ }\end{array}$ & 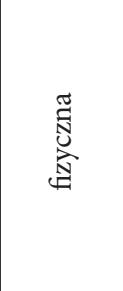 & \begin{tabular}{l}
\multirow{J}{*}{} \\
స్ర
\end{tabular} & $\frac{\tilde{0}}{\stackrel{0}{3}}$ \\
\hline 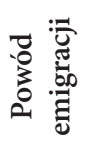 & 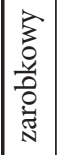 & $\begin{array}{l}\hat{3} \\
0 \\
0 \\
0 \\
0 \\
3 \\
\text { N }\end{array}$ & 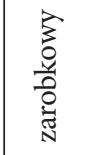 & $\begin{array}{l}3 \\
0 \\
0 \\
\frac{y}{0} \\
0 \\
0 \\
\text { N̦ }\end{array}$ & 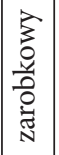 & 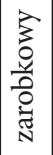 & 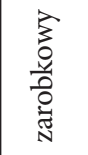 & 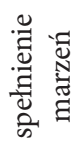 & 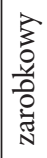 & 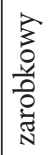 & 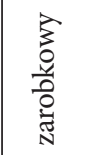 & 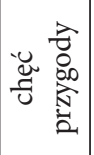 & 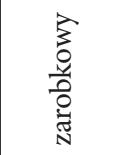 & 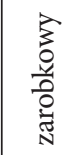 & 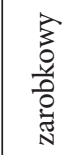 \\
\hline 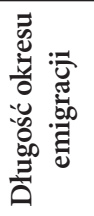 & 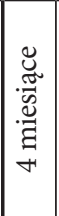 & 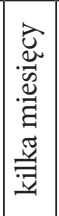 & $\frac{\vec{\pi}}{\sim}$ & $\frac{\frac{\pi}{\tilde{m}}}{m}$ & $\frac{\pi}{10}$ & $\frac{\vec{J}}{\stackrel{I}{J}}$ & $\frac{\pi}{F}$ & 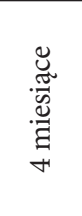 & 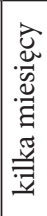 & $\frac{\pi}{10}$ & $\frac{\vec{\sigma}}{n}$ & $\frac{\pi}{6}$ & 등 & 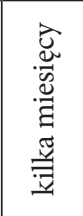 & 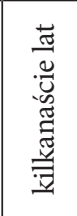 \\
\hline 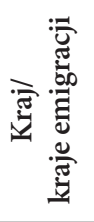 & 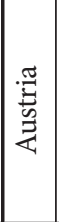 & 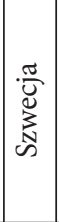 & 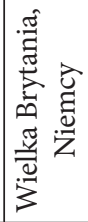 & 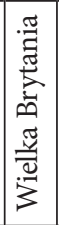 & 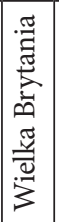 & 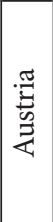 & 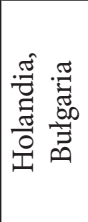 & 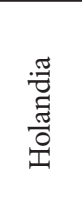 & . & 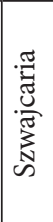 & $\frac{\pi}{\frac{\pi}{0}}$ & 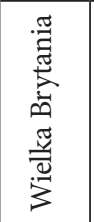 & 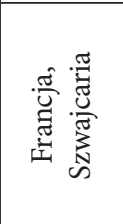 & 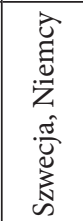 & 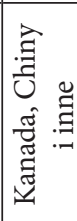 \\
\hline 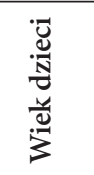 & ㄱ. & $\hat{\tilde{a}}$ & $\begin{array}{l}\infty \\
\stackrel{-}{=} \\
\stackrel{n}{=}\end{array}$ & 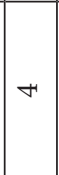 & ㄱ. & in & 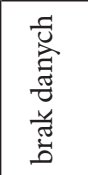 & 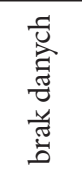 & 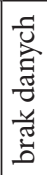 & 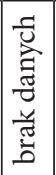 & $\hat{\sigma}$ & $\psi$ & $\psi$ & $\widetilde{N}$ & $\stackrel{1}{\hat{N}}$ \\
\hline 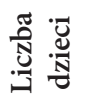 & - & $\sim$ & $m$ & - & - & - & N & $v$ & $\sim$ & - & v & - & - & - & - \\
\hline $\begin{array}{l}\text { D. } \\
\text { 总 } \\
\text { N }\end{array}$ & 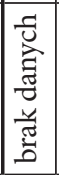 & 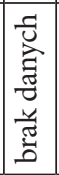 & 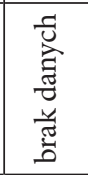 & 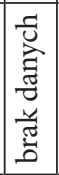 & 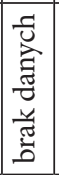 & 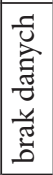 & 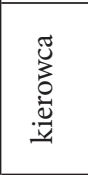 & 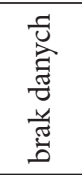 & 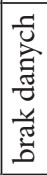 & 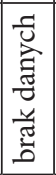 & 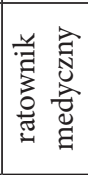 & 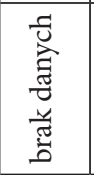 & 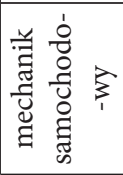 & 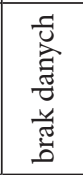 & 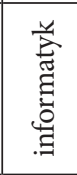 \\
\hline 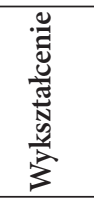 & 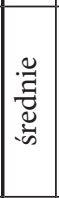 & 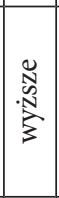 & 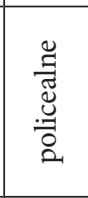 & 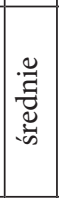 & 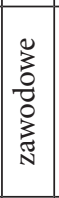 & 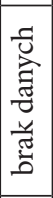 & 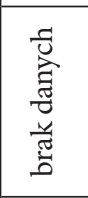 & 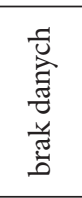 & 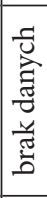 & 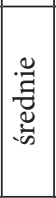 & 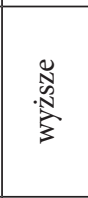 & 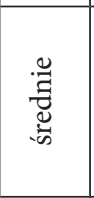 & 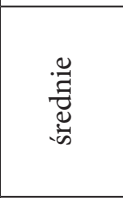 & 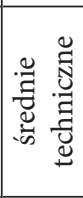 & 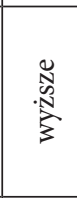 \\
\hline$\frac{\pi}{3}$ & I & $\underset{F}{*}$ & $\stackrel{1}{f}$ & $\stackrel{\sim}{\sim}$ & กิ & $\vec{n}$ & in & 우 & in & $\stackrel{\sim}{\sim}$ & 구 & $\ddot{n}$ & $\hat{\curvearrowright}$ & $\stackrel{\mathscr{q}}{*}$ & $\stackrel{n}{m}$ \\
\hline 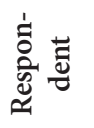 & 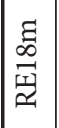 & 竞 & $\begin{array}{l}\text { 동 } \\
\text { 工્વ }\end{array}$ & 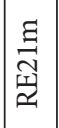 & 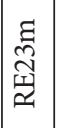 & 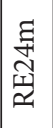 & 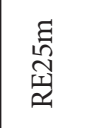 & 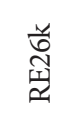 & 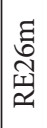 & 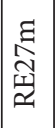 & $\begin{array}{l}\text { ב } \\
\text { స్ } \\
\text { પ્વ }\end{array}$ & $\begin{array}{l}\text { तै } \\
\text { ज्ञ }\end{array}$ & 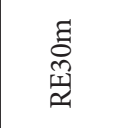 & $\underset{\Xi}{\Xi}$ & 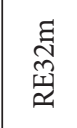 \\
\hline$\stackrel{\dot{1}}{=}$ & $\cong$ & $\stackrel{\infty}{-}$ & 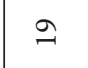 & ‡) & $\vec{\sim}$ & $\approx$ & $\ddot{\sim}$ & $\stackrel{H}{\sim}$ & $\stackrel{\stackrel{2}{\sim}}{\mathrm{N}}$ & $\stackrel{\circ}{\sim}$ & $\widehat{\imath}$ & $\stackrel{\infty}{\sim}$ & $\stackrel{\curvearrowright}{\sim}$ & ஓ & $\vec{m}$ \\
\hline
\end{tabular}


Na 31 badanych większość, a więc 26 osób stanowią mężczyźni. Najmłodszy respondent miał 26 lat, najstarszy - 52. Prawie połowę badanych stanowiły osoby w przedziale wieku 25-40 lat. Najczęściej deklarowanym wykształceniem jest wykształcenie średnie i średnie techniczne. Najkrótszy okres wyjazdu to kilka miesięcy, najdłuższy - 15 lat. Najpopularniejsze kierunki wyjazdu to Wielka Brytania, Irlandia, Niemcy. Wyjazdy były powodowane chęcią zarobienia pieniędzy, a zatem, posługując się przywołaną wcześniej typologią emigrantów, większość z nich to „chomiki”. Z wcześniejszych badań, których ustalenia przytaczałam w poprzednim podrozdziale wynika, że dzieci łatwiej znoszą emigracje przeżycia (a z takimi mamy tu w większości do czynienia) niż emigracje, mające na celu realizację niekończących się potrzeb konsumpcyjnych.

$\mathrm{Na}$ emigracji badani podejmowali w większości proste prace fizyczne w budownictwie, rolnictwie i usługach. Można zatem przyjąć, że moja próba badawcza, jeśli chodzi o społeczno-demograficzne cechy, nie odbiega od charakterystyk emigrantów z badań ogólnopolskich.

Jeśli chodzi o sytuację rodzinną badanych, większość posiada jedno dziecko. Wiek dzieci jest różny. Najmłodsze dziecko w chwili badania miało kilka miesięcy, najstarsze - 27 lat. Obecne w próbie kobiety, zgodnie ze społecznymi oczekiwaniami, wyemigrowały w chwili, gdy ich dzieci miały więcej niż 10 lat. Tylko w jednym przypadku w momencie badania respondentka miała czteroletnie dziecko, a zaczęła swoją, jak sama to określiła, przygodę z emigracją, jeszcze przed jego urodzeniem. W związku z tym jej sytuacja jest specyficzna, gdyż emigrowała już wcześniej, a urodzenie dziecka spowodowało jedynie czasowe zawieszenie wyjazdów.

\section{Zakres modyfikacji roli ojca, matki i dziecka}

Proces modyfikacji ról $\mathrm{w}$ rodzinie migrującej jest zazwyczaj rozciągnięty w czasie. Członkowie rodziny metodą „prób i błędów” starają się wzajemnie dopasować do siebie. Rodzic emigrujący przejmuje na siebie ciężar utrzymania rodziny, nawet jeśli drugi rodzic też jest osobą pracującą. W związku z tym obowiązkiem i odległością staje się on niejako "rodzicem na trzy czwarte”. W okresie wyjazdów uczestniczy w życiu rodziny przez kontakt telefoniczny i mailowy.

Sposób i zakres pełnienia roli rodzica przez osobę emigrującą zależy nie tylko od jego chęci i potrzeby, ale także od tego, na ile pozostający w kraju rodzic pozwala mu nim być. Rodzice stacjonarni starają się często pokazać, 
że radzą sobie doskonale w pojedynkę i - co już zauważyli inni badacze tego zjawiska - przefiltrowują informacje na temat zachowywania się dzieci w taki sposób, aby oddzielić informacje dotyczące pozytywnych zachowań dziecka, które mają służyć jako dowód tego, że będący na miejscu rodzic doskonale radzi sobie w podwójnej roli matki i ojca, od informacji o nagannym zachowaniu dziecka, które mogłoby w negatywnym świetle postawić oboje rodziców - rodzica stacjonarnego, bo nie radzi sobie $\mathrm{z}$ obowiązkami na miejscu i rodzica emigrującego, ponieważ nie ma go, gdy jest potrzebny. Świadczy o tym poniża wypowiedź emigranta posiadającego 17-letniego syna, który jest na emigracji od 4 lat:

Zresztą mój syn wiedział, jaka jest sytuacja, wiedział, że wszystkim jest trudno i naprawę starał się nie dostarczać dodatkowych problemów. Przynajmniej tak mi się wydaje. Musiałbyś zapytać moją żonę. (RE5m: 57-59)

Nie wydaje się możliwe, aby $\mathrm{w}$ tak długim czasie nastolatek nie sprawiał żadnych problemów wychowawczych. Natomiast jest prawie pewne, że żona respondenta starała się radzić sobie $\mathrm{z}$ nimi sama, nie obciążając dodatkowo męża problemami w domu. A oto inna wypowiedź ojca-emigranta dotycząca jego kontaktów z dorastającymi córkami:

Znaczy ja zadowolony jestem. Układają mi się relacje z córkami. Córki też nie dają mi znać, że coś jest nie tak. (RE25m: 195-96)

Badany uważa swoje relacje $\mathrm{z}$ dziećmi za dobre, mimo czasowego oddalenia, gdyż córki nie informują go o jakichkolwiek problemach, trudnościach. Uważa zatem, że skoro nie mówią o niczym niepokojącym, to znaczy, że wszystko jest w porządku. Postawa respondenta jest całkowicie bierna. Bywa, że migrujący rodzice, chcąc chronić siebie i dobre relacje $\mathrm{z}$ rodziną przed negatywnymi informacjami, nie podejmują rozmów na tematy mogące prowadzić do konfliktów, gdyż w sytuacji oddalenia i tak trudno byłoby je rozwiązać, a wywołany konflikt wpłynąłby negatywnie na, często, nie najlepsze (wskutek przepracowania i tęsknoty za rodziną) samopoczucie emigranta.

Wyjątek od zaobserwowanej reguły filtrowania informacji z domu stanowią tu dwie sytuacje. Pierwsza, gdy rodzic stacjonarny chce przyspieszyć przedłużający się powrót partnera $\mathrm{z}$ wyjazdu lub wpłynąć na niego, żeby zaprzestał dalszych wyjazdów. Druga sytuacja, gdy dziecko sprawia poważne problemy wychowawcze, których na dłuższą metę nie da się tuszować i gdy wspólnie trzeba podjąć decyzję dotyczącą poradzenia sobie z tym problemem. 
Bywa też, że rodzic emigrujący dowiaduje się o zaistniałych problemach po czasie, kiedy są one już zażegnane. Rodzic stacjonarny może wówczas opowiedzieć historię $\mathrm{z}$ happy endem i w ten sposób udowodnić drugiej stronie własną zaradność. Tego typu sytuacje obrazuje poniższa wypowiedź:

(...) była kiedyś taka sytuacja, że żona w domu była, jak bardzo to mówi przeżyła, taka że dziecko akurat stukło sobie jakoś tam nogę, gdzieś tam bawiło się, i po prostu taka panika tak, bo nie było mnie, nie miał kto zawieźć do szpitala i takie szukanie tam taksówek, czy po znajomych, żeby tam po prostu załatwić, więc to tak, tak stresująca, powiedzmy, sytuacja dla niej, no i dla mnie, jak się później dowiedziałem to troszkę też takie, no ale poradziła sobie. (RE2m: 61-65)

Inną formą modyfikacji roli rodzica na czas emigracji jest czasowe zastępstwo w roli ojca/matki, które pełni zazwyczaj członek najbliższej rodziny.

Tak naprawdę rolę ojca, podczas mojej nieobecności pełniła moja żona. W sumie teść również starał się być nie tylko dziadkiem, ale i ojcem. Był jedynym mężczyzną, który przebywał wtedy z nimi, więc był też pewnego rodzaju wzorem dla Michała. (RE5m: 53-56)

Również w sytuacji emigracji matki inne dorosłe kobiety w rodzinie (babcie, ciocie), często na wyraźną prośbę osoby wyjeżdżającej przejmują część opieki nad pozostawionym dzieckiem. Z powyższych danych wynika, iż hipoteza H1 zyskała potwierdzenie.

\section{Rodzaje i częstotliwość interakcji w rodzinach badanych migracyjnych}

Częstotliwość kontaktu emigranta $\mathrm{z}$ rodziną jest rozmaita na różnych etapach emigracji. Na początku kontakty są częste, codzienne i sprowadzają się do kilkugodzinnych rozmów. Podczas następnych wyjazdów ma miejsce przyzwyczajenie do sytuacji emigracji, a rodzina wypracowuje sobie pewien schemat komunikacji i swoiste kody komunikacyjne, które nie wymagają już tak intensywnych rozmów na co dzień, za wyjątkiem sytuacji nadzwyczajnych, kiedy trzeba omówić jakiś problem, podjąć ważną decyzję.

Kontaktujemy się przez Skype’a jak większość osób będących na emigracji. A co do częstotliwości, to rozmawiamy praktycznie codziennie, może teraz trochę mniej niż na początku, bo wtedy było to kilka godzin dziennie, ale jest to obecnie w granicach godziny. (RE8k: 58-65) 
$\mathrm{Z}$ kolei rodzaj interakcji z dziećmi różnicuje wiek dzieci. Te interakcje, które mają na celu pełnienie roli rodzica na odległość, nazwałam strategiami rodzicielskimi i podzieliłam na strategie realizowane na bieżąco i strategie odroczone. Ich zestawienie zawiera tabela 2.

Tab.2. Rodzaj podejmowanych strategii rodzicielskich przez rodziców-emigrantów a wiek dzieci

\begin{tabular}{|c|c|c|}
\hline $\begin{array}{c}\text { RODZAJ } \\
\text { STRATEGII }\end{array}$ & DZIECI W WIEKU DO 6 LAT & DZIECI W WIEKU POWYŻEJ 6 LAT \\
\hline 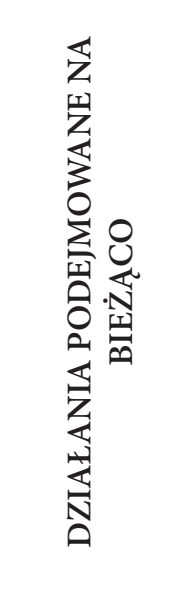 & $\begin{array}{l}\text { - bardzo rzadkie w odniesieniu } \\
\text { do bardzo małych dzieci } \\
\text { - rozmowy telefoniczne (oswa- } \\
\text { janie małego dziecka z głosem } \\
\text { rodzica), rozmowy przez } \\
\text { Internet } \\
\text { - prośby o przesyłanie zdjęć, } \\
\text { rysunków dzieci - komento- } \\
\text { wanie ich, rozmowy o nich } \\
\text { - staranie się „bycia } \\
\text { poinformowanym” }\end{array}$ & $\begin{array}{l}\text { - odrabianie lekcji przez Internet } \\
\text { - częste wysyłanie sms-ów, rozmowy telefo- } \\
\text { niczne lub przez komunikatory internetowe; } \\
\text { główne tematy rozmów: } \\
\text { - } \text { udzielanie niezbędnych porad dotyczących } \\
\text { dnia codziennego } \\
\text { - } \text { wysłuchiwanie relacji z przebiegu dnia } \\
\text { - } \text { kontrolowanie ocen i postępów w szkole } \\
\text { - } \text { przypominanie o obowiązkach } \\
\text { - } \text { porady zdrowotne } \\
\text { - } \text { wsparcie psychiczne, rozmowy } \\
\text { o uczuciach } \\
\text { - } \text { przypominanie o motywach wyjazdu, tłu- } \\
\text { maczenie sytuacji }\end{array}$ \\
\hline 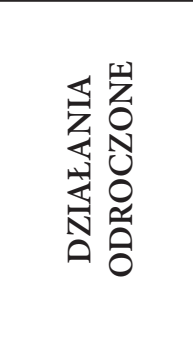 & $\begin{array}{l}\text { - kupowanie prezentów } \\
\text { - poświęcanie większości czasu } \\
\text { na zabawy z dzieckiem }\end{array}$ & $\begin{array}{l}\text { - kupowanie prezentów } \\
\text { - uleganie wszelkim prośbom dzieci, za- } \\
\text { spokajanie kaprysów lub przeciwnie eg- } \\
\text { zekwowanie autorytetu celem szybkiego } \\
\text { skorygowania zaobserwowanych zachowań } \\
\text { ocenianych jako negatywne } \\
\text { - częste rozmowy, okazywanie zainteresowania } \\
\text { - wspólne wyjazdy }\end{array}$ \\
\hline
\end{tabular}

Źródło: opracowanie na podstawie wyników badań własnych.

Jeśli chodzi o wspomniane strategie wychowawcze podejmowane przez rodziców - emigrantów, można zauważyć pewne prawidłowości:

- więcej działań na bieżąco jest podejmowanych w odniesieniu do starszych dzieci z uwagi na możliwość lepszego porozumienia się z nimi za pomocą telefonu czy Internetu.

- Zarówno działania podejmowane na bieżąco, jak i działania odroczone są bogatsze w odniesieniu do starszych dzieci. 
- Kobiety-emigrantki niezależnie od wieku dzieci podejmują więcej działań na bieżąco, a mężczyźni-emigranci - więcej działań odroczonych. Być może ma to związek $\mathrm{z}$ ciągle jeszcze powszechnie panującym przekonaniem, że matka jest „ważniejszym” rodzicem i w większym stopniu odpowiada za zaniedbania wychowawcze niż ojciec. Ojciec może na jakiś czas „zawiesić” lub „zminimalizować” swoją rolę wychowawczą i nie będzie to mieć negatywnych konsekwencji dla dziecka.

Bywa, że mimo chęci kontaktu i potrzeby bycia rodzicem mimo oddalenia przeszkodą jest niemożność pogodzenia terminu kontaktu z uwagi na odmienny tryb życia na emigracji i w kraju.

Rozmawialiśmy przez telefon, Skype’a, dzieci wysyłały mi też wiadomości emailem ze swoimi zdjęciami albo rysunkami dla mnie. Staraliśmy się rozmawiać jak najczęściej, ale wiadomo było to trudne, bo ja miałem czas wieczorem, kiedy one już spały albo rano, gdy córka była w szkole. Najczęściej rozmawialiśmy w weekendy, wtedy to żona zawsze dbała o to. Rozmawialiśmy o tym jak nam minął tydzień córka opowiadała jak było w szkole i jak mijają jej przygotowania do komunii, a mały chwalił się tym, co już potrafi powiedzieć. (RE3m: 138-143)

Większość rozmów między dziećmi a wyjeżdżającymi rodzicami dotyczy codzienności, aktualnych spraw. Ich „referowanie” przez dziecko daje emigrującemu rodzicowi poczucie „bycia na bieżąco”, a dziecku - poczucie, że mimo wyjazdu rodzic uczestniczy w jego życiu.

A o czym najczęściej rozmawiacie podczas tych rozmów?

O wszystkim. Najczęściej oczywiście o tym, co słychać w domu i co słychać u mnie. Na początku odrabiałam z synem nawet lekcje przez Skype’a. Było to możliwe dzięki kamerze. $Z$ czasem syn nie tak chętnie odrabiał ze mną lekcje, więc musieliśmy trochę zmienić temat, pojawiły się pierwsze miłości i różne inne rzeczy związane $\mathrm{z}$ dorastaniem syna. (RE8k: 58-65)

Bywa, że rodzic emigrujący jest $\mathrm{w}$ stanie udzielić niezbędnej pomocy w większym zakresie niż rodzic stacjonarny. Tego typu sytuacje sprawiają, że dziecko nabiera przekonania, że może liczyć na mamę lub tatę, mimo że nie są z nim na co dzień.

Pamiętam, że raz córka się rozchorowała i męża nie było wtedy w domu i wysłała mi sms-a, że chce pogadać, bo nie wie co ma robić. Usiadłam przy skypie (niestety dopiero po pracy) i udzieliłam Jej wskazówek, co robić, pocieszyłam i od razu było lepiej. (RE18k: 57-59) 
Niewątpliwie jednym z nieczęsto dostrzeganych pozytywów wyjazdu rodzica jest większe partnerstwo w relacji rodzic - dziecko. Dzieci są traktowane jako równorzędni partnerzy interakcji i pytani o zdanie w różnych sprawach. To buduje poczucie własnej wartości i ważności u dziecka i pozytywnie wpływa na jego funkcjonowanie w szerszym otoczeniu społecznym.

$Z$ reguły były to rozmowy telefoniczne (także przez Skype’a). Odbywały się praktycznie codziennie. Rozmowy z dziećmi dotyczyły raczej bieżących spraw i opinii dzieci na temat przeprowadzki za granicę, tłumaczenia im zaistniałej sytuacji. (RE12m)

Jak zauważyli niemal wszyscy respondenci, najtrudniejszym momentem jest powrót z roli rodzica na odległość do roli rodzica będącego na miejscu.

Dzieci po moim powrocie traktowały mnie jak gościa. Przed wyjazdem miałem jakiś autorytet, a po powrocie musiałem znów zaczynać wychowanie na nowo. (RE15m: 54-55)

Po powrocie trzeba na nowo określić relacje w domu, przyzwyczaić siebie i dziecko do swojej obecności i do bycia rodzicem na „cały etat”. Zgromadzone dane świadczą o prawdziwości hipotezy $\mathrm{H} 2$.

\section{Zdrowie emigranta a funkcjonowanie w rodzinie migracyjnej}

Poprosiłam respondentów o opisanie przeciętnego dnia pracy na emigracji z wyszczególnieniem godzin w pracy, wykonywanych zajęć, pór posiłków, czasu relaksu oraz pory i godzin snu. $Z$ narracji tych powstał obraz emigranta, który przez kilka miesięcy emigracji wykorzystuje maksymalnie dobę na to, żeby zarobić jak najwięcej pieniędzy, zakumulować jak najwięcej kapitału, pracując nierzadko na dwóch etatach. Czas snu jest ograniczony, a pory posiłków - nieregularne. Same posiłki są przygotowywane zgodnie z zasadą oszczędzania pieniędzy. Kupuje się najtańsze, a więc mniej wartościowe produkty. Czas poza pracą właściwie nie istnieje, a jeśli zdarzy się wolna godzina, to jest ona wykorzystywana na regenerację, oglądanie telewizji i rozmowę z innymi emigrantami, najczęściej współlokatorami. Tryb życia emigranta określiłabym mianem "koszarowego" i nie pozostaje on bez wpływu na zdrowie i samopoczucie emigranta. 
Telefon do domu też często ma miejsce o jednej i tej samej porze, co wprowadza pewną harmonię i poczucie kontroli nad sytuacją. Najczęściej telefon do domu ma miejsce o tej porze dnia, kiedy emigrant jest już bardzo zmęczony i w związku z tym sam też stara się nie podejmować rozmów na tematy potencjalnie drażliwe. Rozmowa $\mathrm{z}$ rodziną ma zrelaksować, uspokoić po wytężonym dniu pracy i przygotować do kolejnego równe wytężonego dnia pracy. Zdarza się jednak, że emigrant wyładowuje złość i frustrację związaną z przeciążeniem pracą na partnerze lub dzieciach. Podobne sytuacje mają oczywiście miejsce w rodzinach bez doświadczeń wyjazdowych, kiedy rodzic przychodzi zmęczony z pracy, ale tu odległość działa jako dodatkowy czynnik pogłębiający rodzący się konflikt i wpływający ujemnie na relacje z dzieckiem, ponieważ jakość komunikacji między małżonkami/partnerami wpływa na jakość komunikacji między emigrującym rodzicem a dzieckiem. Dziecko wyczuwając napiętą atmosferę często nie chce podejść do telefonu lub rozmawiać przez komunikator. Tym samym potwierdzenie zyskuje hipoteza H3.

\section{Podsumowanie, wnioski końcowe i rekomendacje}

Odwołując się do typologii W. Danilewicz, badane przeze mnie rodziny to $\mathrm{w}$ większości rodziny o zaburzonym charakterze wspólnoty (typ trzeci). Pojedyncze rodziny można potraktować jako przykłady rodzin - wspólnot rozłączonych przestrzennie (typ czwarty) lub rodzin, które mimo emigracji są wspólnotami emocjonalnymi (typ piąty). Oznacza to, iż dla większości badanych przeze mnie emigrantów wyjazd zarobkowy zmienił relacje w rodzinie i miał zarówno negatywne jak i pozytywne konsekwencje. Żadnej z rodzin nie dotknął jednak rozpad emocjonalny ani tym bardziej rozpad strukturalny.

W wypowiedziach emigrantów oraz rodziców stacjonarnych przebijają starania o to, żeby emigracja nie wpłynęła negatywnie na życie rodzinne. Wymaga to często dużego samozaparcia i samodyscypliny. Co ciekawe, emigrujący mężowie często podkreślają, że ich dobry kontakt z dzieckiem mimo oddalenia był/jest możliwy dzięki staraniom żon, które też często przestrzegają swoich partnerów przed wchodzeniem w rolę „świętego Mikołaja”. Pełnienie roli rodzica na odległość jest możliwie, ale ma też swoje ograniczenia. Podejmowane wówczas strategie rodzicielskie są specyficzne dla tej sytuacji, ale nie następuje przerwanie procesu wychowawczego i opiekuńczego. To, jak rodzina emigracyjna będzie funkcjonować, jaka będzie jej kondycja, w dużej mierze zależy też od zewnętrznego wsparcia i braku napiętnowania społecznego. Warto by- 
łoby też pomyśleć o swego rodzaju szkoleniach z technik rozmawiania z dzieckiem na odległość i technik wychowywania na odległość. Rodziny migracyjne nie znikną szybko z pejzażu społecznego. Nie są one patologią samą w sobie, choć media usiłują to udowadniać w licznych, szokujących materiałach, ale mogą je dotknąć pewne formy patologii czy trudności nieobcych innego typu rodzinom. Patologia w rodzinach $\mathrm{z}$ doświadczeniem emigracji zarobkowej nie jest normą, ale ryzykiem, przed którym można się ustrzec.

\section{Bibliografia}

Boćwińska-Kiluk B. (2012), Jakość przywiązania $w$ relacji matki z dzieckiem jako predyktor występowania zaburzeń więzi u dzieci i dorostych, [w:] T. Rostowska, A. Lewandowska-Walter (red.), Małżenstwo i rodzicielstwo a zdrowie, Toruń

Danilewicz W. (2003), Dziecko w rodzinie rozłaczonej, [w:] J. Izdebska (red.), Dziecko w rodzinie $i$ środowisku rówieśniczym, Białystok

Danilewicz W. (2007), Społeczne konsekwencje migracji zagranicznych, [w:] D. Lalak (red.), Migracja, uchodźstwo, wielokulturowość. Zderzenie kultur we wspótczesnym świecie, Warszawa

Danilewicz W. (2010), Rodzina ponad granicami. Transnarodowe doświadczenia wspólnoty rodzinnej, Białystok

Erenreich B., Hochschild A. R. (2004), Global Woman. Nannies, Maids and Sex Workers in the New Economy, New York

Gizicka D., Gorbaniuk J., Szyszka M. (2010), Rodzina w sytuacji rozłąi migracyjnej, Lublin

Grabowska-Lusińska I. (2012), Migrantów ścieżki zawodowe bez granic, Warszawa

Korczyńska J. (2003), Sezonowe wyjazdy zarobkowe Polaków do Niemiec, Warszawa

Kozak S. (2010), Patologia eurosieroctwa w Polsce. Skutki migracji zarobkowej dla dzieci i ich rodzin, Warszawa

Kubitsky J. (2012), Psychologia migracji, Warszawa

Małek A. (2011), Migrantki-opiekunki. Doświadczenia migracyjne Polek pracujących w Rzymie, Kraków

Michałek J. (2010), Jakość życia w świetle zjawiska migracji, [w:] T. Rostowska, A. Jarmołowska (red.), Rozwojowe $i$ wychowawcze aspekty życia rodzinnego, Warszawa

Muszel M. (2013), Tradycyjna rola w nietradycyjnej rodzinie. Transnarodowa migracja polskich żon i matek - studium przypadku, http://interalia.org.pl [25.05.2013]

Parrenas R. S. (2001), Motering form a Distanse: Emotions, Gender, and Intergenerational Relations in Filipo Transnational Families, "Feminist Studies" nr 27 (2)

Patino L.R. i in. (2005), Migration, family dysfunction and psychotic symptoms in children and adolescents, "British Journal of Psychiatry" nr 186

Siek E. J. (2011), Migracje zagraniczne na pobyt stały w Polsce po akcesji do UE, [w:] M. Noga, M. K. Stawicka (red.), Rynek pracy w Polsce $w$ dobie integracji europejskiej i globalizacji, Warszawa 
Sytuacja demograficzna Polski. Raport 2006-2007, 2007, Rządowa Rada Ludnościowa, Rządowe Centrum Studiów Strategicznych, Warszawa

Szczygielska I. (2013), Migracje zarobkowe kobiet i ich wyptyw na funkcjonowanie rodzin, Warszawa

Trusz S., Kwiecień M. (2012), Społeczne piętno eurosieroctwa, Warszawa 


\section{SUMMARY}

\section{Mom, Can You Tell Me a Story via Skype? Families with the Experience of Work Migration: Negotiating and Expanding the Range of Family Roles}

Work migration is one of the contemporary phenomena that became the focus of numerous researches. Its political and economic outcomes in both the country of origin and the recipient country seem to be well dealt with in a vast number of treatises. The new migration wave, however, brought about a number of completely new specific phenomena. As a result of the last post accession wave of work migration from Poland, which began 1st May 2004, there appeared: pendulum migration strategy, transnational parenthood, euro-orphanage, and nanny syndrome. In the article, I analyze one of them, i.e. transnational parenthood. I will focus on the direction in which the roles of a mother, a father, a child and other members of a family experiencing pendulum migration change and the range of the modification. I am also interested in the migrants' and their families' social life and how their health is affected by the functioning in such families. I based my dissertation on immensely rich literature on the subject as well as my own research material gathered since 2010, which includes quality interviews with both migrants and their family members.

\section{Keywords:}

family, work migration, transnational parenthood, euro-orphanage 